\title{
Biochemical characterization of three putative ATPases from a new type IV secretion system of Aeromonas veronii plasmid pAC3249A
}

\author{
Ashraf Y Rangrez ${ }^{1,2}$, Mohammad Y Abajy ${ }^{3}$, Walter Keller ${ }^{3}$, Yogesh Shouche ${ }^{1 *}$, Elisabeth Grohmann ${ }^{2 *}$
}

\begin{abstract}
Background: Type four secretion systems (TFSS) are bacterial macromolecular transport systems responsible for transfer of various substrates such as proteins, DNA or protein-DNA complexes. TFSSs encode two or three ATPases generating energy for the secretion process. These enzymes exhibit highest sequence conservation among type four secretion components.

Results: Here, we report the biochemical characterization of three ATPases namely TraE, TraJ and TraK (VirB4, VirB11 and VirD4 homologs of the Agrobacterium tumefaciens transfer system, respectively) from the transfer system of Aeromonas veronii plasmid pAC3249A. ATPases were expressed as His-tag fusion proteins in E. coli and purified by affinity chromatography. ATP binding and ATP hydrolysis experiments were performed with the purified ATPases. TraE and Trak showed strong binding to TNP-ATP and TNP-CTP (fluorescent analogs of ATP and CTP respectively) whereas TraJ showed weak binding. The optimum temperature range for the three ATPases was between $42^{\circ} \mathrm{C}$ and $50^{\circ} \mathrm{C}$. Highest ATP hydrolysis activity for all the ATPases was observed in the presence of $\mathrm{Mg}^{2+}$ and $\mathrm{Mn}^{2+}$. However, TraJ and TraK also showed activity in the presence of $\mathrm{Co}^{2+}$. TraJ exhibited the highest specific activity of all the three ATPases with $v_{\max } 118 \pm 5.68 \mathrm{nmol} / \mathrm{min} / \mathrm{mg}$ protein and $K_{M} 0.58 \pm 0.10 \mathrm{mM}$.

Conclusions: This is the first biochemical characterization of conjugative transport ATPases encoded by a conjugative plasmid from Aeromonas. Our study demonstrated that the three ATPases of a newly reported TFSS of A. veronii plasmid pAc3249A are functional in both ATP hydrolysis and ATP binding.
\end{abstract}

\section{Background}

TFSS are promiscuous macromolecular transporters of Gram-negative and Gram-positive bacteria that mediate intercellular transfer of various substrates, e.g. proteins, DNA or protein-DNA complexes between bacteria or between bacteria and eukaryotic cells [1-5]. The bacterial conjugation machines form a subgroup of TFSS. They mediate the spread of antibiotic resistance genes and virulence traits among bacterial populations. Agrobacterium tumefaciens uses an archetypal TFSS composed of VirD4, also called coupling protein and VirB1VirB11 mating pair formation proteins [6]. TFSS encode two or three ATPases belonging to the P-loop NTPase family [1,7]. These ATPases exhibit the highest sequence

\footnotetext{
* Correspondence: yogesh@nccs.res.in; elisabeth.grohmann@tu-berlin.de 'Molecular Biology Unit, National Centre for Cell Science, Pune 411007, India ${ }^{2}$ Department of Environmental Microbiology, Technical University of Berlin, Franklinstr. 29, FR1-2, D-10587 Berlin, Germany
}

conservation among TFSS components [1]. They are also characterized by highly conserved nucleotide binding Walker A (GxxGxGKT/S) and Walker B (hhhhDE) motifs [8].

By transfer DNA immunoprecipitation assay, Atmakuri et al. demonstrated that the three energetic components, VirD4, VirB11 and VirB4, mediate successive early steps of the postulated T-DNA translocation pathway [6]. They also suggested that VirD4, VirB11 and VirB4 interact with each other, and that they promote substrate transfer by both ATP-independent and -dependent mechanisms. R388 TrwK (VirB4 homolog), A. tumefaciens VirB11 and Brucella suis VirB11 homo$\log$ BsB11 self-assemble into hexamers and show ATPase activity [9-11]. VirB4 has a role in substrate export, whereas for VirB11 a possible chaperone/morphogenetic function was postulated [12]. Evidence for VirB4 self-association [13] and structural contribution
C Biomed Central

(c) 2010 Rangrez et al; licensee BioMed Central Ltd. This is an Open Access article distributed under the terms of the Creative Commons Attribution License (http://creativecommons.org/licenses/by/2.0), which permits unrestricted use, distribution, and reproduction in any medium, provided the original work is properly cited. 
to channel formation independent of ATPase activity has been shown $[10,14,15]$. ATPases are also considered as potential drug targets to prevent the spread of diseases. Hilleringmann et al. (2006) showed that inhibitors of Helicobacter pylori ATPase Cagalpha (VirB11 homo$\log$ ) block CagA transport and cag virulence [16]. VirD4-like proteins, so called coupling proteins (CP) are considered to link the DNA transfer intermediate to, and perhaps lead it through the mating channel [17]. Coll and coworkers proposed an elegant model based upon the crystal structure of TrwB, the CP of plasmid R388 [17-19]. The strong structural resemblance of TrwB with ring helicases suggests that the transferred ssDNA might pass through the central channel of the TrwB hexamer, thereby entering the translocation apparatus. ATP hydrolysis would provide the energy to pump the ssDNA through the TrwB channel [18].

Recently, we reported a TFSS encoded by plasmid pAc3249A in A. veronii consisting of twelve ORFs including three ATPases [20]. The genetic organization of the A. veronii TFSS is represented in Figure 1. The Aeromonas species used in this study was initially proposed as a novel bacterium, A. culicicola [21], which was later defined as a strain belonging to the species $A$. veronii [22]. A. veronii is a Gram-negative, rod-shaped bacterium. In humans $A$. veronii can cause diseases ranging from wound infections and diarrhoea to septicaemia in immune compromised patients [23-25]. In this study, we have biochemically characterized the three ATPases TraE, TraJ and TraK (VirB4, VirB11 and VirD4 homologs of A. tumefaciens respectively) by ATP binding and ATP hydrolysis experiments. We defined the optimum $\mathrm{pH}$ and temperature range of ATP hydrolysis and the requirement of divalent cations.

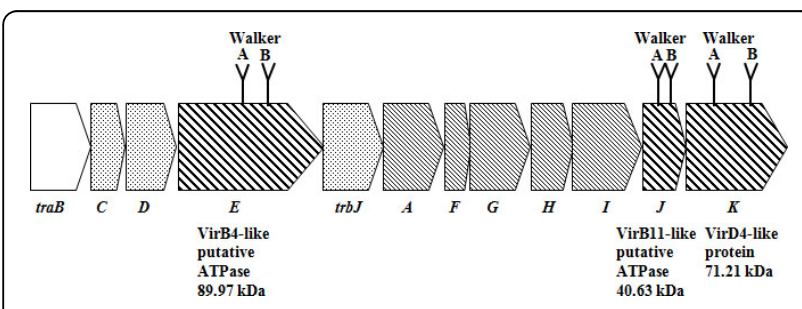

Figure 1 Organization of the pAc2349A tra region. Different fillings of the orfs are indicative of the putative role of the deduced protein. $t r a B$ is the gene coding for a putative lytic transglycosylase (homologous to VirB1 of the Agrobacterium T-DNA transfer system). Dotted segments represent putative components of pilus assembly whereas thin lined segments represent proteins forming the core complex. Thick lined segments code for three putative ATPases; TraE and TraJ show the conserved nucleotide binding site motif $A$ (Walker A box) and a motif B (Walker B box) of proteins belonging to the VirB4 and VirB11 family of nucleoside triphosphate binding proteins respectively. TraK is a member of the pfam02534 family of TraG/TrwB/TraD/NirD4 coupling proteins. It shows the P-loop motif (Walker A box) and a Walker B motif for nucleotide binding.

\section{Results}

\section{Overexpression and purification of TFSS ATPases}

TraE, TraJ and TraK were overproduced in E. coli XL10 as His-tagged recombinant proteins and purified by affinity chromatography. Purity of the proteins was checked by SDS-PAGE (Figure 2). TraE and TraK migrate at 90 $\mathrm{kDa}$ and $70 \mathrm{kDa}$ in the denaturing PAGE according to their expected molecular mass of $89.97 \mathrm{kDa}$ and 71.21 $\mathrm{kDa}$, respectively. However, the TraJ band migrates at approximately $35 \mathrm{kDa}$, significantly faster than expected for its calculated molecular mass of $40.63 \mathrm{kDa}$ (Figure 2). Expression of TraE, TraJ and TraK resulted in $2.3 \mathrm{~g}$, $2.1 \mathrm{~g}$ and $1.8 \mathrm{~g}$ of cells per liter culture. The yield of purified TraE, TraJ and TraK was approximately $2.8 \mathrm{mg}$, $2.5 \mathrm{mg}$ and $2 \mathrm{mg}$ per liter culture respectively. Highly pure eluted fractions of TraE, TraJ and TraK from NiNTA affinity column were concentrated to $0.5-1 \mathrm{mg} / \mathrm{mL}$ for enzymatic characterization.

\section{TraE, TraJ and TraK show ATP binding activity in vitro}

Purified TraE, TraJ and TraK were used for nucleotide binding assays using TNP-ATP and TNP-CTP. The study revealed that all three ATPases show in vitro ATP binding. The ATP binding activity of TraE was higher than that of TraJ and TraK (Figures 3, 4 and 5). In case of TraE and TraK, there was a shift in the absorption maximum after binding to TNP-ATP (Figures 3 and 5). Binding studies with TNP-CTP gave similar results. TNP-CTP binding affinity of TraE was also higher than that of TraJ and TraK. However, the binding affinity for all the ATPases was higher for ATP than for CTP (Figures 3 and 5).

\section{TraE, TraJ and TraK exhibit ATP hydrolysis activity}

Further characterization revealed that TraE, TraJ and TraK exhibit in vitro ATP hydrolysis activity. The ATP hydrolysis activity was highest for TraJ (118.0 \pm 5.68

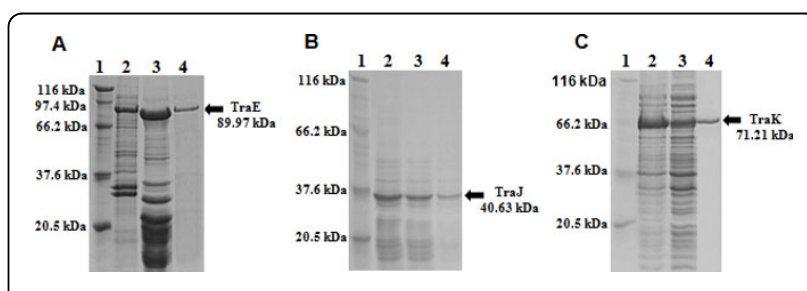

Figure 2 12\% SDS-PAGE showing the purification of the TraE, TraJ and TraK proteins. A. lane 1 - low molecular mass marker (Jena Biosciences, Jena, Germany), 2 - supernatant, 3 - lysate (E. coli XL10 pQTEV-traE), 4 - eluate of Ni-NTA column, B. lane 1 - low molecular mass marker, 2 - lysate (E. coli XL10 pQTEV-traf), 3 supernatant, 4 - eluate of Ni-NTA column and C. lane 1 - low molecular mass marker, 2 - supernatant, 3 - lysate (E. coli XL10 pQTEV-traK), 4 - eluate of Ni-NTA column. Mobility of TraE and TraK is in agreement with their calculated molecular mass. However, TraJ runs faster than its predicted molecular mass of $40.63 \mathrm{kDa}$. 


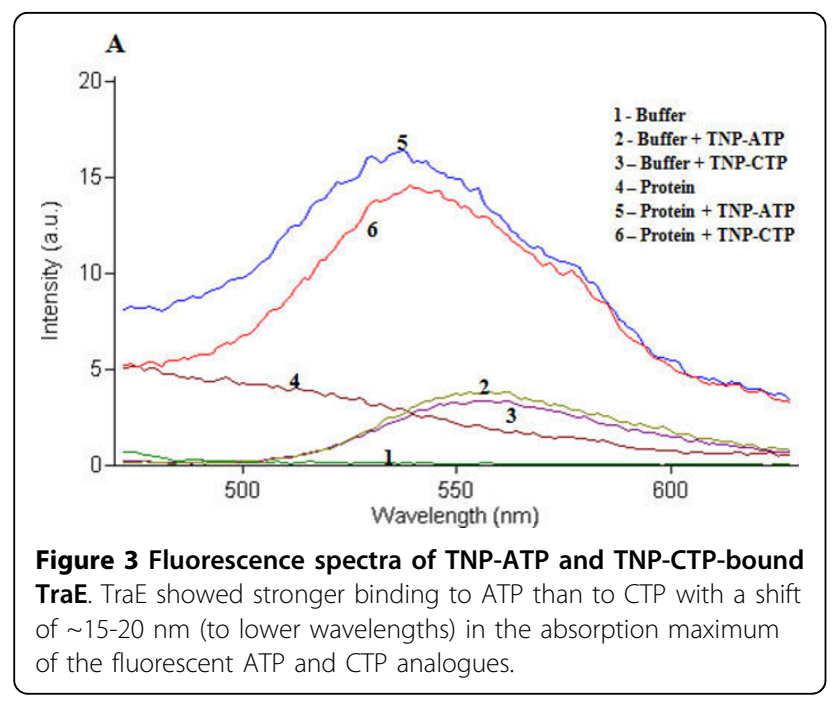

$\mathrm{nmol} / \mathrm{min} / \mathrm{mg}$ protein), lower for TraK $(82.76 \pm 6.82$ $\mathrm{nmol} / \mathrm{min} / \mathrm{mg}$ protein) and lowest for TraE (53.35 \pm $3.64 \mathrm{nmol} / \mathrm{min} / \mathrm{mg}$ protein) (Figure 6). As derived from a Michaelis-Menten plot, the $\mathrm{K}_{\mathrm{M}}$ of TraE, TraJ and TraK was $0.55 \mathrm{mM}, 0.58 \mathrm{mM}$ and $0.92 \mathrm{mM}$, respectively. The estimated $K_{M}$ value for TraK is significantly higher than that observed for TraE and TraJ showing its lower affinity for ATP. Utilization of other nucleotides such as CTP, GTP, TTP and ADP as substrate in the hydrolysis assay was also studied. Maximum hydrolyzing activity for TraE was found to be associated with both ATP and TTP. TraJ hydrolysis activity was two times higher with CTP as compared to ATP whereas TraK hydrolyzed TTP more efficiently than other nucleotides (Figure 7).

To eliminate the possibility of the presence of any other contaminant ATPase in the purified TraE/TraJ/ TraK fractions, the purified relaxase (TraL) (which was

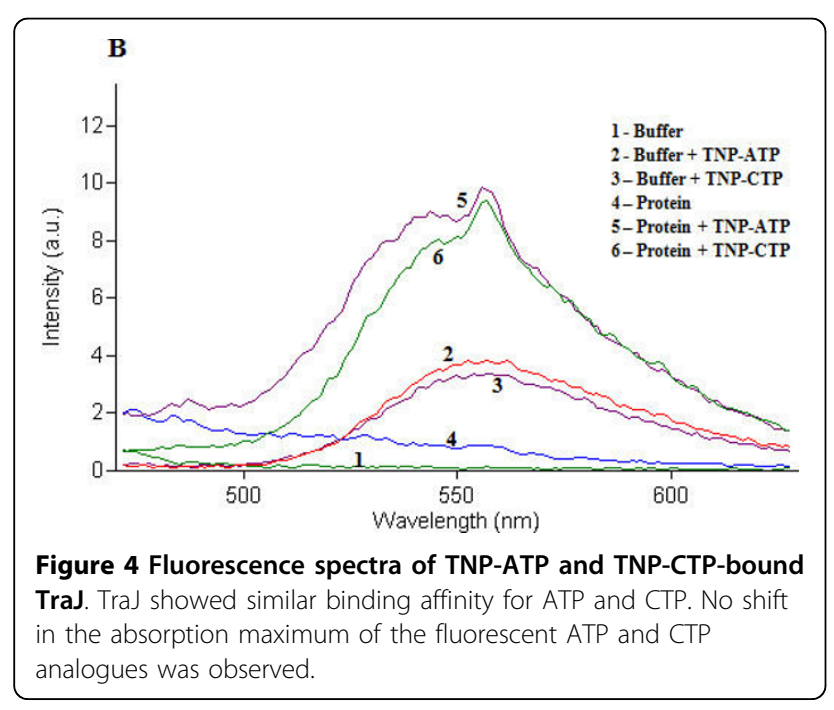

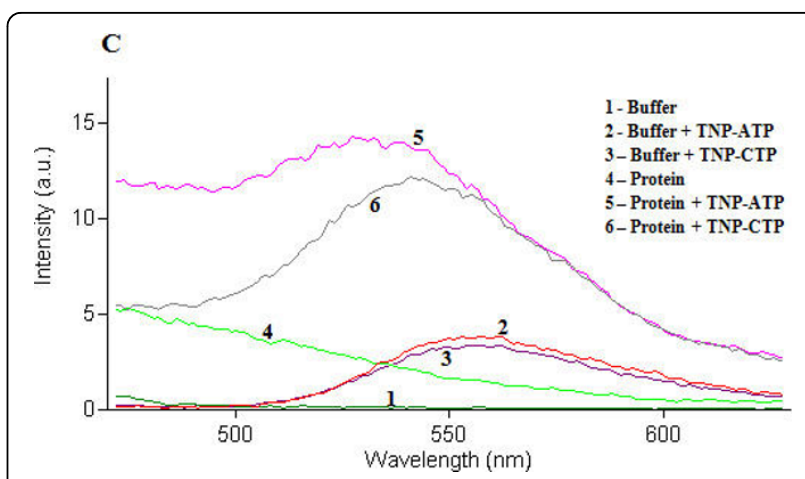

Figure 5 Fluorescence spectra of TNP-ATP and TNP-CTP-bound TraK. Trak showed stronger binding activity to ATP than to CTP with a shift of $\sim 15-20 \mathrm{~nm}$ (to lower wavelengths) in the absorption maximum of the fluorescent ATP and CTP analogues.

overproduced and purified following the procedure applied for TraE, TraJ and TraK) was used as a control in ATP binding and hydrolysis experiments (AYR and WK, unpublished data). Neither ATP binding nor ATP hydrolysis activity was observed for the relaxase, ruling out the possibility of any ATPase contamination.

\section{$\mathrm{Mg}^{2+}$ is the best cofactor for TraE, TraJ and TraK ATPase activity}

We analyzed seven different divalent metal ions $\left(\mathrm{Mg}^{2+}\right.$, $\mathrm{Cu}^{2+}, \mathrm{Co}^{2+}, \mathrm{Zn}^{2+}, \mathrm{Ca}^{2+}, \mathrm{Mn}^{2+}$ and $\mathrm{Ni}^{2+} 10 \mathrm{mM}$ each) in an ATPase assay to define the cofactor requirement of TraE, TraJ and TraK. $\mathrm{Mg}^{2+}$ was observed to be the best cofactor followed by $\mathrm{Mn}^{2+}$ for ATPase activity of all the three ATPases (Figure 8). Surprisingly, ATPase activity of $\mathrm{TraK}$ in presence of $\mathrm{Mg}^{2+}$ and $\mathrm{Co}^{2+}$ was nearly the

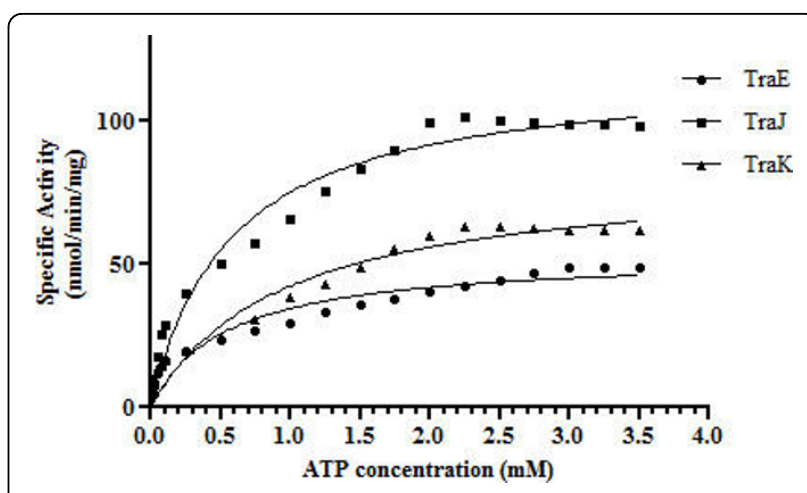

Figure 6 Kinetic study of TraE, TraJ and TraK ATPase activity. ATP hydrolysis was monitored as a function of ATP concentration and kinetic parameters were calculated by Michealis-Menten plot. From $v_{\max }$ and $K_{M}$ values, it can be concluded that the ATP hydrolyzing activity of TraJ is higher than that of TraE and TraK. TraK has lower affinity for ATP as compared to TraE and TraJ. ATPase activity is given in nmol inorganic phosphate generated per min and per mg of the respective protein. The values are mean of three independent measurements. 


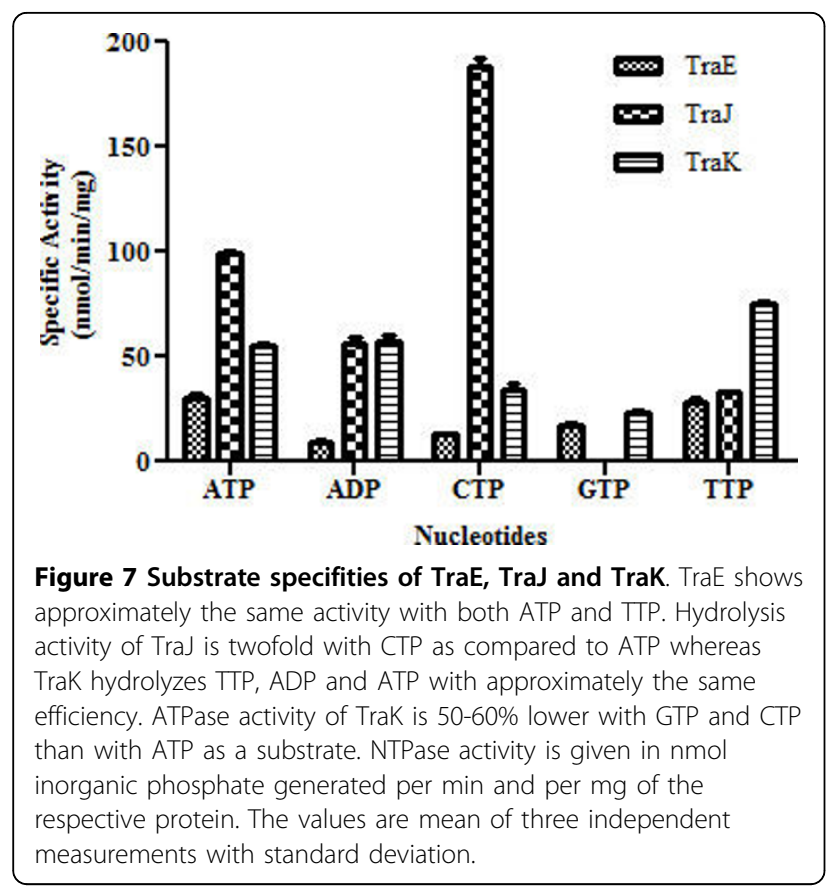

same (Figure 8). However, $\mathrm{Cu}^{2+}, \mathrm{Zn}^{2+}, \mathrm{Ca}^{2+}$ and $\mathrm{Ni}^{2+}$ were less effective in activating the ATP hydrolysis activity of the ATPases.

TraE, TraJ and TraK are active between pH 6.5 - 8.0

The effect of different buffers on ATPase activity was studied to determine the optimum $\mathrm{pH}$ for the ATP hydrolysis activity of TraE, TraJ and TraK. A set of buffers ranging from $\mathrm{pH} 5.0$ to 9.5 (sodium citrate $(\mathrm{pH} 5.0$

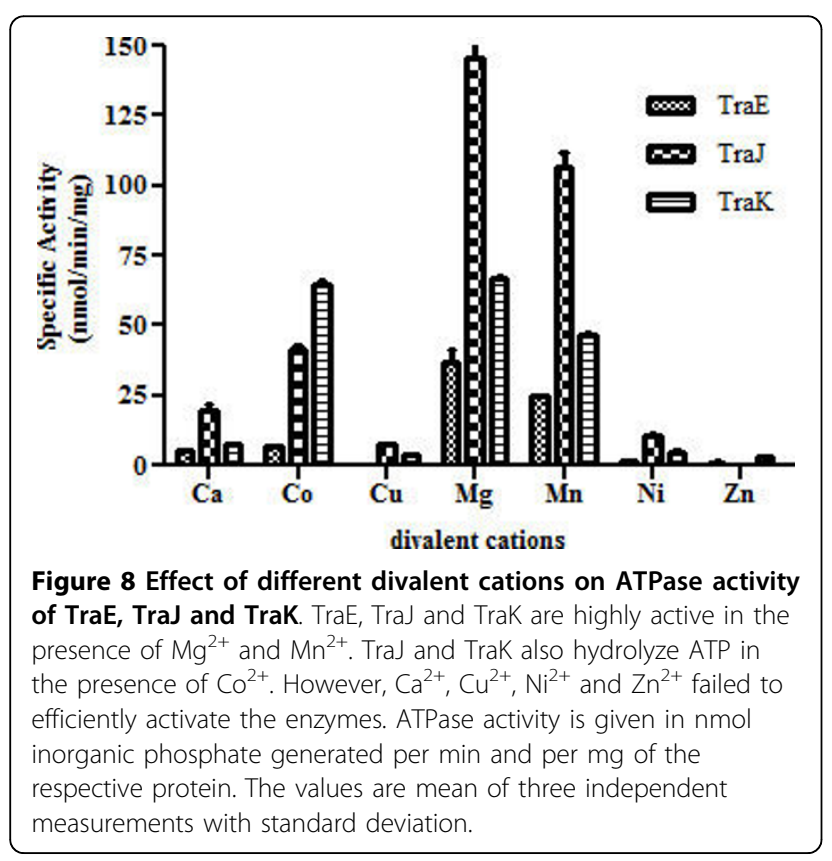

- 5.5), sodium phosphate (6.0 - 6.5), HEPES-NaOH $(\mathrm{pH}$ 7.0), Tris- $\mathrm{HCl}$ (pH 7.5 - 8.5), and sodium borate- $\mathrm{NaOH}$ (pH 9.0 - 9.5)) were used to determine the $\mathrm{pH}$ optimum. The optimal ATPase activity of TraE, TraJ and TraK was observed within a $\mathrm{pH}$ range of 6.5 to 8.0, with highest activities for TraE and TraK at $\mathrm{pH} 7.0$ and for TraJ at pH 7.5 (Figure 9). Notably, ATP hydrolysis activity for TraE declined gradually beyond the optimum $\mathrm{pH}$ range. However, ATP hydrolysis by TraJ and TraK dropped sharply outside the optimum $\mathrm{pH}$ range (Figure 9).

\section{Optimum temperature range for TraE, TraJ, and TraK ATPase activity is $36^{\circ} \mathrm{C}-50^{\circ} \mathrm{C}$}

ATPase activity of TraE, TraJ and TraK was measured over the temperature range of $10-80^{\circ} \mathrm{C}$ (Figure 10). Approximately $60-80 \%$ of the total ATPase activity for all the ATPases was observed within a temperature range of $36-50^{\circ} \mathrm{C}$. Maximum activity for TraJ and TraK occurred at $42^{\circ} \mathrm{C}$ and for TraE the optimum temperature observed was $45^{\circ} \mathrm{C}$. At lower temperatures (below $36^{\circ} \mathrm{C}$ ), only $10-15 \%$ activity was measured. However, at temperatures between $60^{\circ} \mathrm{C}-70^{\circ} \mathrm{C}, 15-20 \%$ of the total activity was retained. It sharply dropped to less than $5 \%$ at $80^{\circ} \mathrm{C}$ (Figure 10).

\section{Discussion}

TraE, TraJ and TraK (VirB4, VirB11 and VirD4 homologs of the A. tumefaciens TFSS respectively) are components of the first putative conjugative TFSS of Aeromonas. Here we present a functional characterization of these ATPases of $A$. veronii plasmid pAc3249A. Like other transport ATPases, TraE, TraJ and TraK

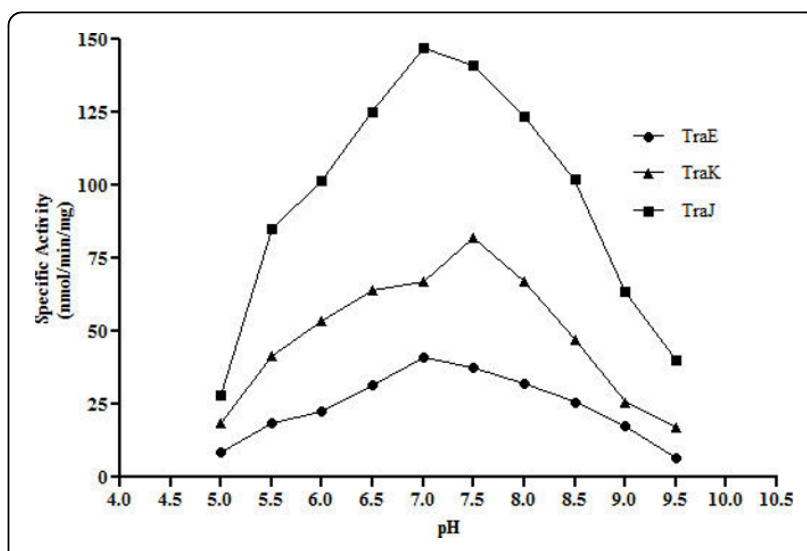

Figure 9 Effect of pH on ATPase activity of TraE, TraJ and TraK. ATPase assays were performed in different buffers to analyze the effect of pH on enzyme activity. The optimum pH observed for TraK is 7.5 and for TraE and TraJ it is pH 7.0. ATPase activity is given in nmol inorganic phosphate generated per min and per mg of the respective protein. The values are mean of three independent measurements. 


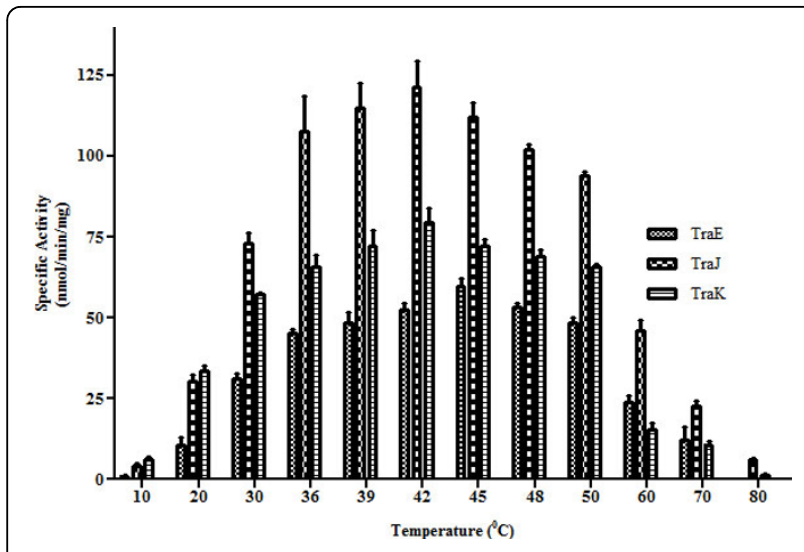

Figure 10 Effect of temperature on ATPase activity of TraE, TraJ and TraK. ATP hydrolysis activity of TraE, TraJ and TraK is plotted against increasing temperatures. The optimum temperature range for TraE, TraJ and TraK is between $36^{\circ} \mathrm{C}$ and $50^{\circ} \mathrm{C}$. All three ATPases retain moderate ATP hydrolysis activity at $60^{\circ} \mathrm{C}$. ATPase activity is given in nmol inorganic phosphate generated per min and per $\mathrm{mg}$ of the respective protein. The values are mean of three independent measurements with standard deviation.

possess two conserved nucleotide binding Walker A and B motifs [6]. The Walker A motifs for TraE (GATGAGKT) and TraJ (GGTGSGKT) follow the conserved motif suggested for all P-loop NTPases (GxxGxGKT) [8]. The Walker A motif of TraK (APTRSGKG) shows the conserved nucleotide binding motif of CPs. Three ATPases of the first putative TFSS of Aeromonas were over-expressed and purified for biochemical characterization. In vitro characterization directly demonstrated that TraE, TraJ and TraK bind and hydrolyze nucleotides effectively acting as an ATPase. Purified TraE, TraJ and TraK displayed $\mathrm{Mg}^{2+}$ dependent ATPase activity with $\mathrm{v}_{\max }$ of $53.35,118.0$ and $82.76 \mathrm{nmol} / \mathrm{min} / \mathrm{mg}$ protein and $\mathrm{K}_{\mathrm{M}}$ of $0.55,0.58$ and $0.96 \mathrm{mM}$, respectively.

Nucleotide binding assays using TNP-ATP and TNPCTP, respective fluorescent analogs of ATP and CTP, showed that TraE, TraJ and TraK exhibit nucleotide binding activity. TraE, TraJ and TraK binding affinity appeared to be higher for TNP-ATP than for TNP-CTP. While TraJ displayed weak, TraE demonstrated strong nucleotide binding affinity for both TNP-ATP and TNP-CTP. Binding of TraE and TraK to TNP-ATP and TNP-CTP resulted in the characteristic 10-20 nm shift in the absorption maximum as observed in previous studies for plasmid RP4 TraG protein and plasmid R388 TrwB protein [26].

The ATPase activity identified for TraE $(53.35 \mathrm{nmol} /$ $\mathrm{min} / \mathrm{mg}$ protein) is comparable with the recently reported activity for its homolog R388 TrwK (48.4 $\mathrm{nmol} / \mathrm{min} / \mathrm{mg}$ protein) [11]. The ATPase activities observed for TraJ (VirB11 homolog) and TraK (VirD4 homolog) are approximately 10 fold higher than the values reported for their respective homologs: plasmid pTiC58 VirB11 and plasmid R388 TrwD presented weak ATPase activity of $1-15 \mathrm{nmol} / \mathrm{min} / \mathrm{mg}$ protein $[27,28]$. The weak activity of these proteins may be attributed to denaturing-renaturing conditions used during protein purification $[27,28]$. In this study, we maintained native conditions for the proteins throughout the extraction and purification steps which likely explain the higher ATPase activities for TraE, TraJ and TraK.

The ATPase activity measured for TraJ is approximately two fold higher than that for TraE and TraK. Though TraE, TraJ and TraK were able to utilize both purine and pyrimidine nucleotides as substrate, we observed major differences in hydrolysis activities with respect to the different nucleotide substrates. TraE exhibited approximately the same hydrolysis activity in the presence of ATP and TTP but only $50-60 \%$ activity (compared to ATP) in the presence of ADP, CTP and GTP. Hydrolysis activity of TraJ was almost twofold higher for CTP than for ATP. However, TraJ could not hydrolyze GTP. TraK utilized TTP most efficiently, followed by ATP and ADP. Interestingly, similar results on substrate selectivity were reported for ExeA, an ATPase involved in the type II secretion pathway of Aeromonas hydrophila [29]. ExeA hydrolyzed GTP and CTP more efficiently than ATP. Although highest hydrolytic rates of TraJ and TraK were obtained with CTP and TTP, respectively, ATP is the likely substrate utilized intracellularly due to the relatively low abundance of other nucleotides in vivo [29].

As expected, $\mathrm{Mg}^{2+}$ was the preferred divalent cation for the ATPase activity of TraE, TraJ and TraK [29]. However, TraJ retained approximately 35\% and TraK $95 \%$ activity in the presence of $\mathrm{Co}^{2+}$ when compared to $\mathrm{Mg}^{2+}$. This observation was surprising considering the low concentration of $\mathrm{Co}^{2+}$ and its toxic effect on bacterial cells $[30,31] . \mathrm{Ca}^{2+}$ was less effective whereas $\mathrm{Cu}^{2+}, \mathrm{Zn}^{2+}$ and $\mathrm{Ni}^{2+}$ were not effective in activating ATP hydrolysis as was the case with the A. hydrophila ATPase [29]. The optimum $\mathrm{pH}$ for TraE and TraJ ATPase activity is around 7.0. This is comparable with the $\mathrm{pH}$ optimum of their respective homologs R388 TrwK (pH 6.5) and R64 PilQ (pH 6.5) [11,32]. We noticed moderate ATPase activity for TraE, TraJ and TraK also above $50^{\circ} \mathrm{C}$. The optimal temperature range for all the ATPases was between $36^{\circ} \mathrm{C}-50^{\circ} \mathrm{C}$. Interestingly, for all of them, the ATP hydrolysis activity observed at $30^{\circ} \mathrm{C}$ was lower than the activity at $50^{\circ} \mathrm{C}$.

The involvement of the pAc3249A TFSS in conjugative plasmid transfer was confirmed by mating experiments (AYR and EG, unpublished data). In triparental mating experiments with $A$. veronii as a donor, we could show mobilization of plasmid pDL277- 
ori $T_{\text {pAc3249A }}$ (a derivative of plasmid pDL277 containing the oriT region of plasmid pAc3249A) to E. coli XL1 blue cells. Further studies on putative key factors of the Aeromonas TFSS are in progress. We are currently characterizing the putative relaxase encoded by the pAc3249A transfer region. In conjunction, these data will elucidate the molecular mechanism of the first TFSS encoded by a plasmid from pathogenic Aeromonas.

\section{Conclusions}

This is the first biochemical characterization of conjugative transport ATPases encoded by a conjugative plasmid from Aeromonas. This study illustrated that the three ATPases, TraE, TraJ, and TraK of the newly reported TFSS of the $A$. veronii plasmid pAc3249A bind and hydrolyze ATP. Ongoing efforts to solve the three dimensional structure of these ATPases will help explain the substrate preferences and nucleotide binding activities of the respective proteins.

\section{Methods}

\section{Cloning of traE, traJ and traK}

The traE, traJ and traK genes of plasmid pAc3249A (GenBank ${ }^{\circledR}$ accession number DQ890522) were amplified by PCR using Phusion DNA polymerase (New England Biolabs, Frankfurt, Germany) and the specific primers given in Table 1 (Eurofins MWG Operon, Ebersberg, Germany). The PCR products were cut with restriction enzymes $B a m \mathrm{HI}$ and HindIII and purified by PCR cleanup kit (Qiagen, Hilden, Germany). Expression vector pQTEV (Qiagen, Hilden, Germany) was also cut with $B a m \mathrm{HI}$ and HindIII. The ligation mixture was incubated at $16^{\circ} \mathrm{C}$ overnight with $\mathrm{T} 4$ DNA ligase (Roche Diagnostics, Mannheim, Germany) and used for transformation of Escherichia coli XL10 Gold cells (Stratagene, Amsterdam, The Netherlands). Plasmid DNA of selected clones of pQTEV-traE, pQTEV-traJ, and pQTEV-traK was sequenced by SMB (Rüdersdorf, Germany) to confirm the open reading frames.

\section{Expression of TraE, TraJ and TraK}

$5 \mathrm{~mL}$ overnight cultures of the corresponding expression strains (E. coli XL10 Gold cells harbouring pQTEV-traE, pQTEV-traJ, and pQTEV-traK respectively) in LB (Luria-Bertani) medium with $100 \mathrm{mg} / \mathrm{L}$ ampicillin were inoculated in $500 \mathrm{~mL}$ of LB medium with the same antibiotic. Cells were grown until an $\mathrm{OD}_{600}$ of 0.5-0.6 was reached, induced with $0.5 \mathrm{mM}$ isopropyl $\beta$-D-thiogalactopyranoside (Sigma, Taufkirchen, Germany), and grown further at $37^{\circ} \mathrm{C}$ for $4 \mathrm{~h}$.

\section{Purification of TraE, TraJ and TraK}

The E. coli XL10 Gold cells (harbouring pQTEV-traE, pQTEV-traJ, and pQTEV-traK respectively) were harvested by centrifugation, $6000 \mathrm{~g}$ at $4^{\circ} \mathrm{C}$ for $15 \mathrm{~min}$ and resuspended in $100 \mathrm{mM}$ Tris- $\mathrm{HCl}$ (pH 7.6), $100 \mathrm{mM}$ $\mathrm{NaCl}$ and $10 \%$ glycerol (buffer A). Cell lysis was carried out by incubating the suspension with $1 \mathrm{mg} / \mathrm{mL}$ lysozyme at room temperature for $30 \mathrm{~min}$ followed by five cycles of ultrasonication, $1 \mathrm{~min}$ each. Cell debris was removed by centrifugation at $25000 \mathrm{~g}$ at $4^{\circ} \mathrm{C}$ for $30 \mathrm{~min}$. The supernatant was loaded onto a $\mathrm{Ni}^{2+}$ charged $\mathrm{Ni}$ NTA (Qiagen, Hilden, Germany) affinity column equilibrated with buffer A. The column was first washed with buffer A followed by two washes with buffer A containing $30 \mathrm{mM}$ and $40 \mathrm{mM}$ imidazole respectively. The respective protein (TraE/TraJ/TraK) was eluted in buffer A with $250 \mathrm{mM}$ imidazole. The purification process was monitored by $12 \%$ SDS-PAGE. Eluted fractions of high purity were pooled and concentrated by centrifugation with the Amicon CentriPrep system (molecular mass cut-off of $10 \mathrm{kDa}$ ) (Millipore, Vienna, Austria). The concentrated proteins were used for nucleotide binding and hydrolysis studies.

\section{NTP hydrolysis assay}

The NTP hydrolysis assay was performed in $50 \mu \mathrm{l}$ reactions as described by Lanzetta et al. (1979) with minor modifications [33]. The standard reaction mixture containing $2.5 \mu \mathrm{g}$ of TraE, TraJ or TraK protein, $2.5 \mathrm{mM}$ ATP and $10 \mathrm{mM} \mathrm{MgCl}_{2}$ in buffer A (100 mM Tris- $\mathrm{HCl}$

Table 1 Primers used for the amplification of traE, traJ and traK genes of plasmid pAc3249A (GenBank accession number DQ890522).

\begin{tabular}{llcc}
\hline Primer & Sequence $\mathbf{( 5}^{\prime} \mathbf{3}^{\prime}$ ) & Target gene & $\begin{array}{c}\text { Nucleotide position } \\
\text { (in pAc3249A) }\end{array}$ \\
\hline traE_f & GCCGGATCCATGAAGCAGATAAAGCA & traE & $1250-1266$ \\
\hline traE_r & GCCAAGCTTACTCACTCTTCTCTCAGTTG & $3605-3623$ \\
traJ_f & GCCGGATCCATGTTCCGAGAAATATT & traJ & $8007-8023$ \\
\hline traJ_r & GCCAAGCTTACTTAAATTGATTCACTCAGC & trak & $9066-9085$ \\
trak_f & GCCGGATCCATGAAAAATAAAGCGG & & $9099-9115$ \\
trak_r & GCCAAGCTTACaTTATTCTGATTATCAGC & $10965-10983$ \\
\hline
\end{tabular}

Nucleotides shown in bold indicate the restriction sites, GGATCC - BamHI and AAGCTT - HindIII. 
(pH 7.6), $100 \mathrm{mM} \mathrm{NaCl}$ and $10 \%$ glycerol) was incubated at $37^{\circ} \mathrm{C}$ for $30 \mathrm{~min}$. Furthermore, the effect of different ATP concentrations $(0.025 \mathrm{mM}-3.5 \mathrm{mM})$, different nucleotides $(2.5 \mathrm{mM}$ each), different divalent cations (10 mM each), different $\mathrm{pH}(\mathrm{pH} 5-\mathrm{pH} 9.5)$ and different temperatures $\left(10^{\circ} \mathrm{C}-80^{\circ} \mathrm{C}\right)$ on hydrolysis activity was analyzed. The reactions were stopped by the addition of $800 \mu \mathrm{l}$ of a colour reagent (3:1 ratio of $0.045 \%$ malachite green and $4.2 \%$ ammonium molybdate in $4 \mathrm{~N} \mathrm{HCl}$ ) and $100 \mu \mathrm{l}$ of $34 \%$ citric acid solution. After incubation at room temperature for $30 \mathrm{~min}$, the absorbance was measured at $660 \mathrm{~nm}$. One unit of ATPase activity was defined as the hydrolysis of $1 \mathrm{nmol}$ of ATP $/ \mathrm{min} / \mathrm{mg}$ of the respective protein. Three independent experiments were performed for each parameter and graphs were plotted using mean values and standard deviations wherever appropriate.

\section{Nucleotide binding assay}

The nucleotide binding assay was performed following the method described in Schröder and Lanka [26]. The fluorescent nucleotide analogues TNP-ATP (Invitrogen Life Sciences, Karlsruhe, Germany) and TNP-CTP (Jena Biosciences, Jena, Germany) were used as substrates. Briefly, $0.5-1 \mathrm{mg} / \mathrm{mL}$ protein (TraE, TraJ or TraK) in $500 \mu \mathrm{l}$ buffer A (100 mM Tris- $\mathrm{HCl}$ (pH 7.6), $100 \mathrm{mM}$ $\mathrm{NaCl}$ and $10 \%$ glycerol) was incubated for $20 \mathrm{~s}$ with TNP-ATP $(15 \mu \mathrm{g})$ or TNP-CTP $(15 \mu \mathrm{g})$ at room temperature. Fluorescence spectra were taken at room temperature by using a Varian Cary Eclipse spectrofluorometer (Varian Inc., Palo Alto, USA) with excitation at $410 \mathrm{~nm}$ and emission scanning in the range of 470 to $630 \mathrm{~nm}$. The fluorescence maxima were determined graphically.

\section{Abbreviations Used}

TFSS: type IV secretion system; CP: coupling protein; ORF: open reading frame; TNP-ATP: 2',3'-O-(2,4,6-trinitrophenyl) adenosine 5'-triphosphate; TNP-CTP: 2',3'-O(2,4,6-trinitrophenyl) cytidine 5'-triphosphate; ss: single stranded; NTP: nucleotide tri-phosphate.

\section{Acknowledgements}

AYR is thankful to the DAAD (German Academic Exchange Service) for providing the sandwich fellowship. We also thank Kumari Manju for critical reading of the manuscript.

\section{Author details \\ ${ }^{1}$ Molecular Biology Unit, National Centre for Cell Science, Pune 411007, India. ${ }^{2}$ Department of Environmental Microbiology, Technical University of Berlin, Franklinstr. 29, FR1-2, D-10587 Berlin, Germany. ${ }^{3}$ Institute for Molecular Biosciences, Karl-Franzens-University Graz, Humboldtstrasse 50/3, A-8010 Graz, Austria.}

\section{Authors' contributions}

AYR, YS, WK and EG designed the experimental strategy for this study. AYR and MYA were involved in standardization of the experimental conditions.
AYR was involved in acquisition of the data. AYR, WK and EG analyzed and interpreted the data. AYR drafted the manuscript and other authors made corrections to the manuscript. All authors read and approved the final manuscript.

Received: 25 September 2009

Accepted: 9 February 2010 Published: 9 February 2010

\section{References}

1. Christie PJ, Atmakuri K, Krishnamoorthy V, Jakubowski S, Cascales E: Biogenesis, architecture, and function of bacterial type IV secretion systems. Annu Rev Microbiol 2005, 59:451-485.

2. Grohmann E: Mating cell-cell channels in conjugating bacteria. Cell-Cell Channels Georgetown, Texas: Landes BiosciencesBaluska F, Volkmann D, Barlow PW 2006, 21-38.

3. Schell MA, Ulrich RL, Ribot WJ, Brueggemann EE, Hines HB, Chen D, Lipscomb L, Kim HS, Mrázek J, Nierman WC, Deshazer D: Type VI secretion is a major virulence determinant in Burkholderia mallei. Mol Microbiol 2007, 64:1466-1485.

4. Tiaden A, Spirig T, Carranza P, Brüggemann H, Riedel K, Eberl L, Buchrieser C, Hilbi H: Synergistic contribution of the Legionella pneumophila lqs genes to pathogen-host interactions. J Bacteriol 2008, 190:7532-7547.

5. Raychaudhury S, Farelli JD, Montminy TP, Matthews M, Ménétret JF, Duménil G, Roy CR, Head JF, Isberg RR, Akey CW: Structure and function of interacting IcmR-IcmQ domains from a type IVb secretion system in Legionella pneumophila. Structure 2009, 17:590-601.

6. Atmakuri K, Cascales E, Christie PJ: Energetic components VirD4, VirB11 and VirB4 mediate early DNA transfer reactions required for bacterial type IV secretion. Mol Microbiol 2004, 54:1199-1211.

7. Iyer LM, Leipe DD, Koonin EV, Aravind L: Evolutionary history and higher order classification of AAA+ ATPases. J Struct Biol 2004, 146:11-31.

8. Walker JE, Saraste M, Runswick MJ, Gay NJ: Distantly related sequences in the $a$ - and b-subunits of ATP synthase, myosin, kinases and other ATPrequiring enzymes and a common nucleotide binding fold. EMBO J 1982, 1:945-951

9. Rashkova S, Zhou XR, Chen J, Christie PJ: Self-assembly of the Agrobacterium tumefaciens VirB11 traffic ATPase. J Bacteriol 2000, 182:4137-4145.

10. Hare S, Bayliss R, Baron C, Waksman G: A large domain swap in the VirB11 ATPase of Brucella suis leaves the hexameric assembly intact. J Mol Biol 2006, 360:56-66.

11. Arechaga I, Peña A, Zunzunegui S, del Carmen Fernández-Alonso M, Rivas G, de la Cruz F: ATPase activity and oligomeric state of TrwK, the VirB4 homologue of the plasmid R388 type IV secretion system. J Bacteriol 2008, 190:5472-5479.

12. Savvides SN, Yeo HJ, Beck MR, Blaesing F, Lurz R, Lanka E, Buhrdorf R, Fischer W, Haas R, Waksman G: VirB11 ATPases are dynamic hexameric assemblies:new insights into bacterial type IV secretion. EMBO J 2003, 22:1969-1980.

13. Ward DV, Draper O, Zupan JR, Zambryski PC: Peptide linkage mapping of the Agrobacterium tumefaciens vir-encoded T4SS reveals protein subassemblies. Proc Natl Acad Sci 2002, 99:11493-11500.

14. Christie PJ: Type IV secretion: intercellular transfer of macromolecules by systems ancestrally related to conjugation machines. Mol Microbiol 2001, 40:294-305.

15. Tato I, Matilla I, Arechaga I, Zunzunegui S, de la Cruz F, Cabezon E: The ATPase activity of the DNA transporter TrwB is modulated by protein TrwA: implications for a common assembly mechanism of DNA translocating motors. J Biol Chem 2007, 282:25569-25576.

16. Hilleringmann M, Pansegrau W, Doyle M, Kaufman S, MacKichan ML, Gianfaldoni C, Ruggiero P, Covacci A: Inhibitors of Helicobacter pylori ATPase Cag $\alpha$ block CagA transport and cag virulence. Microbiology 2006, 152:2919-2930.

17. Tato I, Zunzunegui S, de la Cruz F, Cabezon E: TrwB, the coupling protein involved in DNA transport during bacterial conjugation, is a DNAdependent ATPase. Proc Natl Acad Sci 2005, 102:8156-8161.

18. Gomis-Rüth FX, Moncalian G, Perez-Luque R, Gonzalez A, Cabezon E, de la Cruz F, Coll M: The bacterial conjugation protein TrwB resembles ring helicases and F1-ATPase. Nature 2001, 409:637-641. 
19. Gomis-Rüth FX, Moncalian G, de la Cruz F, Coll M: Conjugative plasmid protein TrwB, an integral membrane T4SS coupling protein. Detailed structural features and mapping of the active site cleft. J Biol Chem 2002, 277:7556-7566.

20. Rangrez AY, Dayananda KM, Atanur S, Joshi R, Patole MS, Shouche YS: Detection of conjugation related type four secretion machinery in Aeromonas culicicola. PLOS ONE 2006, 1:e115.

21. Pidiyar V, Kaznowski A, Narayan NB, Patole M, Shouche YS: Aeromonas culicicola sp. nov., from the midgut of Culex quinquefasciatus. Int I Syst Evol Microbiol 2002, 52:1723-1728.

22. Huys G, Cnockaert M, Swings J: Aeromonas culicicola Pidiyar et al. 2002 is a later subjective synonym of Aeromonas veronii Hickman-Brenner et al. 1987. Syst Appl Microbiol 2005, 28:604-609.

23. Cui H, Hao S, Arous E: A distinct cause of necrotizing fasciitis: Aeromonas veronii biovar sobria. Surg Infect (Larchmt) 2007, 8:523-528.

24. Gröbner S, Bissinger AL, Raible A, Heeg P, Autenrieth IB, Schmidt SM: Severe diarrhoea caused by Aeromonas veronii biovar sobria in a patient with metastasised GIST. Pol J Microbiol 2007, 56:277-279.

25. Sánchez-Céspedes J, Figueras MJ, Aspiroz C, Aldea MJ, Toledo M, Alperí A, Marco F, Vila J: Development of imipenem resistance in an Aeromonas veronii biovar sobria clinical isolate recovered from a patient with cholangitis. J Med Microbiol 2009, 58:451-455.

26. Schröder G, Lanka E: TraG-like proteins of T4SSs: functional dissection of the multiple activities of TraG (RP4) and TrwB (R388). J Bacteriol 2003, 185:4371-4381.

27. Christie PJ, Ward JEJ, Gordon MP, Nester EW: A gene required for transfer of T-DNA to plants encodes an ATPase with autophosphorylating activity. Proc Natl Acad Sci USA 1989, 86:9677-9681.

28. Rivas S, Bolland S, Cabezon E, Goni FM, de la Cruz F: TrwD, a protein encoded by the IncW plasmid R388, displays an ATP hydrolase activity essential for bacterial conjugation. J Biol Chem 1997, 272:25583-25590.

29. Schoenhofen IC, Li G, Strozen TG, Howard SP: Purification and characterization of the $\mathrm{N}$-terminal domain of ExeA: a novel ATPase involved in the type II secretion pathway of Aeromonas hydrophila. J Bacteriol 2005, 187:6370-6378

30. Thorgersen MP, Downs DM: Cobalt targets multiple metabolic processes in Salmonella enterica. J Bacteriol 2007, 189:7774-7781.

31. Ranquet C, Ollagnier-de-Choudens S, Loiseau L, Barras F, Fontecave M: Cobalt stress in Escherichia coli. The effect on the iron-sulfur proteins. $J$ Biol Chem 2007, 282:30442-30451.

32. Sakai D, Horiuchi T, Komano T: ATPase activity and multimer formation of Pilq protein are required for thin pilus biogenesis in plasmid R64. J Biol Chem 2001, 276:17968-1797.

33. Lanzetta PA, Alvarez $\amalg$, Reinach PS, Candia OA: An improved assay for nanomole amounts of inorganic phosphate. Anal Biochem 1979, 100:95-107.

doi:10.1186/1471-2091-11-10

Cite this article as: Rangrez et al:: Biochemical characterization of three putative ATPases from a new type IV secretion system of Aeromonas veronii plasmid pAC3249A. BMC Biochemistry 2010 11:10.

\section{Submit your next manuscript to BioMed Central and take full advantage of:}

- Convenient online submission

- Thorough peer review

- No space constraints or color figure charges

- Immediate publication on acceptance

- Inclusion in PubMed, CAS, Scopus and Google Scholar

- Research which is freely available for redistribution

Submit your manuscript at www.biomedcentral.com/submit 